\title{
Adipokines: implications for female fertility and obesity
}

\author{
M Mitchell, D T Armstrong, R L Robker and R J Norman \\ Research Centre for Reproductive Health, Department of Obstetrics and Gynaecology, The University of Adelaide, \\ Australia, 5011
}

Correspondence should be addressed to R J Norman; Email: di.sutton@adelaide.edu.au

\begin{abstract}
Obesity is associated with a diverse set of metabolic disorders, and has reproductive consequences that are complex and not well understood. The adipose tissue-produced leptin has dominated the literature with regards to female fertility complications, but it is pertinent to explore the likely role of other adipokines - adiponectin and resistin - as our understanding of their biological functions emerge. Leptin influences the developing embryo, the functioning of the ovary and the endometrium, interacts with the release and activity of gonadotrophins and the hormones that control their synthesis. In this review such biological actions and potential roles of the adipokines leptin, adiponectin and resistin are explored in relation to female fertility and the complexity of the obese metabolic state.

Reproduction (2005) 130 583-597
\end{abstract}

\section{Introduction}

The worldwide incidence of obesity continues to escalate, despite increased awareness and global efforts to understand and confront its origins. In essence, dysregulated energy homeostasis stems from a societal reduction in physical activity, an increase in the accessibility of, and overindulgence in, energy-dense foods, combined with a myriad of genetic, social and economic complicating factors. The mechanisms that control energy metabolism and body fat mass are inherently linked to those that govern fertility and stem back to the evolutionary drive to survive in times of limited food supply. The rising incidence of obesity and associated metabolic disturbances highlights a loss of control in this homeostatic system, which has effects on reproduction, the biology of which remains illdefined but in desperate need of understanding.

Metabolic disorders such as the development of insulin resistance result from the increasing incidence of obesity, and have serious ramifications on the progression of lifetime health problems such as type II diabetes, cardiovascular disease, dyslipidemia and hypertension. A significant proportion of the infertile or sub-fertile population are obese or overweight (Hamilton-Fairley et al. 1992, Zaadstra et al. 1993, Pettigrew \& Hamilton-Fairley 1997, Norman \& Clark 1998, Crosignani et al. 2002), with a plethora of reproductive complications including menstrual dysfunction and anovulation (Hartz et al. 1979, Lake et al. 1997) and miscarriage (Wang et al. 2002). The development of obesity and insulin resistance commonly go hand-in-hand with the development of fertility problems, but it is the link between this metabolic state and infertility that remains to be defined.

Adipose tissue functions as a highly specialised, endocrine and paracrine organ producing an array of adipokines, as well as eliciting cell mediated effects via pro-inflammatory and anti-inflammatory cells, producing various cytokines and chemokines. Such factors have local and systemic biological effects, influence insulin sensitivity and the development of diseases such as atherosclerosis. This review will focus on these adipokines and female fertility, regarding their complex interactions with energy metabolism at the level of the hypothalamus, the pituitary, and peripheral tissues including the gonads, skeletal muscle and adipose tissue. In the last decade the study of one of these adipokines, leptin, has highlighted the interaction with female reproduction. Here, the links between excessive adiposity with obesity and associated metabolic states such as insulin resistance, and interactions with aspects of female fertility will be explored in the context of leptin and two new adipokines, adiponectin and resistin.

\section{Insulin resistance, adipokines and fertility in the obese}

The mechanisms contributing to the impaired physiological effects of insulin commonly described with obesity can be manifest peripherally in muscle and adipose tissue or in the liver. Metabolic consequences evident with the development of insulin resistance include increased 
circulating free fatty acids via elevated lipolysis of triglycerides in adipose tissue and lipoproteins (rich in triglycerides) in other tissues, impaired glucose uptake in muscle and adipose tissue, overproduction of glucose by the liver and overproduction of insulin by pancreatic $\beta$-cells. The obese state is also characterised by features of chronic inflammation, particularly elevated circulating levels of cytokines and inflammatory markers, such as C-reactive protein. Various inflammatory cytokines such as interleukin-6 (IL-6) and tumour necrosis factor- $\alpha$ (TNF- $\alpha$ ), and nuclear receptors including peroxisome proliferator- activated receptor- $\gamma$ (PPAR- $\gamma$ ) have been implicated in the aetiology of insulin resistance associated with obesity. Furthermore the role of adipokines including leptin, resistin and adiponectin with obesity and insulin resistance is emerging (Kadowaki et al. 2003, Greenfield \& Campbell 2004, Eckel et al. 2005)

Evidence supporting an interrelationship between insulin and fertility exists (Gong 2002, Hunter et al. 2004) but the mechanistic actions of dysregulated insulin functioning at a physiological and cellular level as associated with obesity, remain obscure. The adipokines resistin and adiponectin have been touted as this link, because they modulate glucose homeostasis, fat homeostasis, influence insulin action, and thus may potentially mechanistically link obesity, insulin resistance and fertility.

Increased production and secretion of the satiety hormone leptin correlates with the amount of fat tissue in animals (Maffei et al. 1995, Considine et al. 1996). Ordinarily leptin functions to reduce food intake and maintain energy homeostasis, but in obesity the development of a state of leptin resistance results in a dysfunctional energetic state (Sahu 2004). Obese rodents have elevated serum resistin levels (Steppan et al. 2001, Steppan \& Lazar 2002, Lee et al. 2005) but adipose mRNA resistin levels are generally lower or unchanged in these models (Juan et al. 2001, Le Lay et al. 2001, Masuzaki et al. 2001, Way et al. 2001, Milan et al. 2002, Lee et al. 2005), which may be explained by altered translational or post-translational modifications of resistin protein, or altered metabolic clearance of resistin. In humans obese individuals, or those with a higher body mass index (BMI), have higher serum and adipose expression levels of resistin (Savage et al. 2001, Azuma et al. 2003, DegawaYamauchi et al. 2003b, Yannakoulia et al. 2003), although not all studies confer (Lee et al. 2003) and in obese pigs, elevated adipose mRNA and protein levels have been reported (Chen et al. 2004). In contrast, serum and adipose expression levels of adiponectin are reduced in obese humans (Arita et al. 1999, Cnop et al. 2003, Diamond et al. 2004, Bullo et al. 2005), pigs (Jacobi et al. 2004) and rodents (Hu et al. 1996, Yamauchi et al. 2001). Studies investigating the interaction between levels of these adipokines with increased adiposity in obesity, and with nutrition and energy supply in humans and animal models are summarised in Table 1.

\section{Biological functions of adipokines}

Our understanding of the biological significance and functions of leptin, adiponectin and resistin is in its infancy. The potential interactions to regulate energy homeostasis are depicted in Fig. 1.

\section{Leptin}

Leptin, produced predominantly by adipose tissue, was first explored as a satiety signal regulating food intake and energy expenditure. Leptin binds to the long-form of the leptin receptor $(\mathrm{Ob}-\mathrm{Rb})$ in the hypothalamus, to reduce neuropeptide-Y (NPY) and agouti regulated protein (AgRP) activity, to increase pro-opiomelanocortin (POMC) and cocaine- and amphetamine related protein (CART) neuron activity, effectively reducing appetite and feed intake (Hakansson et al. 1996, Mercer et al. 1996, Cheung et al. 1997, Bjorbaek \& Kahn 2004). Deficiencies in leptin signalling or functioning in the hypothalamus are thought to contribute to the development of obesity. A link with insulin resistance and fertility was described early on, with leptin deficient mice having increased adiposity, display severe insulin resistance and diminished fertility, both of which were restored with leptin administration, but not by calorie restriction or weight loss (Chehab et al. 1996, Mounzih et al. 1997).

In peripheral tissues, leptin generally has a fat metabolising role with limited direct effect on glucose metabolism. However, leptin antagonises insulin action and decreases its production by pancreatic $\beta$-cells (Seufert 2004), it indirectly affects glucose metabolism, for example glucose transport in skeletal muscle via the hypothalamus and central nervous system (Kamohara et al. 1997, Minokoshi et al. 1999). Evidence suggests that leptin increases lipolysis in adipose tissue and cells, and in skeletal muscle, but it appears less critical to liver function (Cohen et al. 2001). Leptin receptor signalling in peripheral tissues is not well understood but involves various transcription factors, such as activation of signal transducer and activator of transcription 1 (STAT1) and STAT3 in adipose tissue (Bendinelli et al. 2000) and of STAT3 and Akt in skeletal muscle (Maroni et al. 2003). Furthermore the increase in fatty acid oxidation by leptin in skeletal muscle has been attributed to the activation of the cellular nutrient-sensing AMPactivated protein kinase (AMPK) signalling pathway (Minokoshi et al. 2002, Steinberg et al. 2003).

\section{Adiponectin}

Adiponectin (previously termed by initial investigators: ACRP30; Scherer et al. 1995, AdipoQ; Hu et al. 1996, APM1; Maeda et al. 1996 and gbp28; Nakano et al. 1996), was first described in cultured murine adipocytes 3T3-L1 a decade ago (Scherer et al. 1995) and is abundantly produced by adipose tissue. The adiponectin gene is located on chromosome 3q27 (Saito et al. 1999), in a 
Table 1 Tissue expression and circulating levels of the adipokines adiponectin, resistin and leptin, in genetic and diet-induced obesity, and the influence of nutrient restriction.

\begin{tabular}{|c|c|c|c|c|c|c|c|c|c|}
\hline & \multicolumn{3}{|c|}{ Adiponectin } & \multicolumn{3}{|c|}{ Resistin } & \multicolumn{3}{|c|}{ Leptin } \\
\hline & $\begin{array}{l}\text { mRNA and/or } \\
\text { protein }\end{array}$ & $\begin{array}{l}\text { Circulating } \\
\text { levels }\end{array}$ & Author & $\begin{array}{l}\text { mRNA and/or } \\
\text { protein }\end{array}$ & $\begin{array}{l}\text { Circulating } \\
\text { levels }\end{array}$ & Author & $\begin{array}{l}\text { mRNA and/or } \\
\text { protein }\end{array}$ & $\begin{array}{l}\text { Circulating } \\
\text { levels }\end{array}$ & Author \\
\hline \multirow{3}{*}{$\begin{array}{l}\text { Obese } \\
\text { Human }\end{array}$} & $\downarrow$ & $\downarrow$ & Liu et al. 2003 & $\uparrow$ & & Savage et al. 2001 & & $\uparrow$ & Pagano et al. 2005 \\
\hline & & $\downarrow$ & Pagano et al. 2005 & & - & $\begin{array}{l}\text { Helibronn et al. } \\
2004\end{array}$ & $\uparrow$ & $\uparrow$ & Maffei et al. 1995 \\
\hline & & $\downarrow$ & Arita et al. 1999 & - & - & Pagano et al. 2005 & $\uparrow$ & $\uparrow$ & $\begin{array}{c}\text { Considine et al. } \\
1996\end{array}$ \\
\hline \multirow[t]{5}{*}{$\begin{array}{l}\text { Rodent (diet- } \\
\text { induced) }\end{array}$} & $\downarrow$ & $\downarrow$ & $\begin{array}{l}\text { Makimura et al. } \\
2002\end{array}$ & $\downarrow$ & & Le Lay et al. 2001 & & $\uparrow$ & $\begin{array}{l}\text { Maebuchi et al. } \\
2003\end{array}$ \\
\hline & & $\downarrow$ & $\begin{array}{c}\text { Makimura et al. } \\
2002\end{array}$ & - & $\uparrow$ & Lee et al. 2005 & & & \\
\hline & $\downarrow$ & $\downarrow$ & $\begin{array}{c}\text { Yamauchi et al. } \\
2001\end{array}$ & $\downarrow$ & $\uparrow$ & Rajala et al. 2004 & & & \\
\hline & & & & $\downarrow$ & $\downarrow$ & $\begin{array}{l}\text { Maebuchi et al. } \\
2003\end{array}$ & & & \\
\hline & & & & $\downarrow$ & & $\begin{array}{l}\text { Makimura et al. } \\
2002\end{array}$ & & & \\
\hline \multirow[t]{3}{*}{$\begin{array}{l}\text { Rodent } \\
\text { (genetic) }\end{array}$} & & $\downarrow$ & $\begin{array}{l}\text { Maebuchi et al. } \\
2003\end{array}$ & $\downarrow$ & & Milan et al. 2002 & & $\uparrow$ & $\begin{array}{l}\text { Maebuchi et al. } \\
2003\end{array}$ \\
\hline & $\downarrow$ & & Milan et al. 2002 & $\downarrow$ & $\uparrow$ & Rajala et al. 2004 & & $\uparrow$ & $\begin{array}{l}\text { Wallenius et al. } \\
2002\end{array}$ \\
\hline & & & & $\downarrow$ & & $\begin{array}{l}\text { Maebuchi et al. } \\
2003\end{array}$ & & & \\
\hline Pig & & & & $\uparrow$ & & Chen et al. 2004 & $\uparrow$ & $\uparrow$ & $\begin{array}{l}\text { McNeel et al. } \\
2000\end{array}$ \\
\hline Nutrient restriction & $\uparrow$ & - & Liu et al. 2003 & & - & $\begin{array}{l}\text { Monzillo et al. } \\
2003\end{array}$ & & & $\begin{array}{c}\text { Viguerie et al. } \\
2005\end{array}$ \\
\hline \multirow[t]{4}{*}{ Humans } & & - & $\begin{array}{c}\text { Garaulet et al. } \\
2004\end{array}$ & & - & Lee et al. 2003 & & $\downarrow$ & Maffei et al. 1995 \\
\hline & & $\uparrow$ & $\begin{array}{c}\text { Raitakari et al. } \\
2004\end{array}$ & & & & & $\downarrow$ & $\begin{array}{c}\text { Wadden et al. } \\
1998\end{array}$ \\
\hline & & $\downarrow$ & Wolfe et al. 2004 & & & & $\downarrow$ & $\downarrow$ & $\begin{array}{c}\text { Considine et al. } \\
1996\end{array}$ \\
\hline & $\downarrow$ & - & Xydakis et al. 2004 & & & & & & \\
\hline \multirow[t]{2}{*}{ Rodents } & $\downarrow$ & & $\begin{array}{l}\text { Makimura et al. } \\
2002\end{array}$ & $\downarrow$ & & Milan et al. 2002 & & $\downarrow$ & Maffei et al. 1995 \\
\hline & $\uparrow$ & & Milan et al. 2002 & $\downarrow$ & $\downarrow$ & $\begin{array}{c}\text { Rajala et al. } 2004 \\
\text { Makimura et al. } \\
2002\end{array}$ & & & \\
\hline Pig & & & & $\downarrow$ & & Chen et al. 2004 & & & \\
\hline
\end{tabular}

$\uparrow=$ increased levels; $\downarrow=$ decreased levels; $-=$ no change in levels of adipokines. 


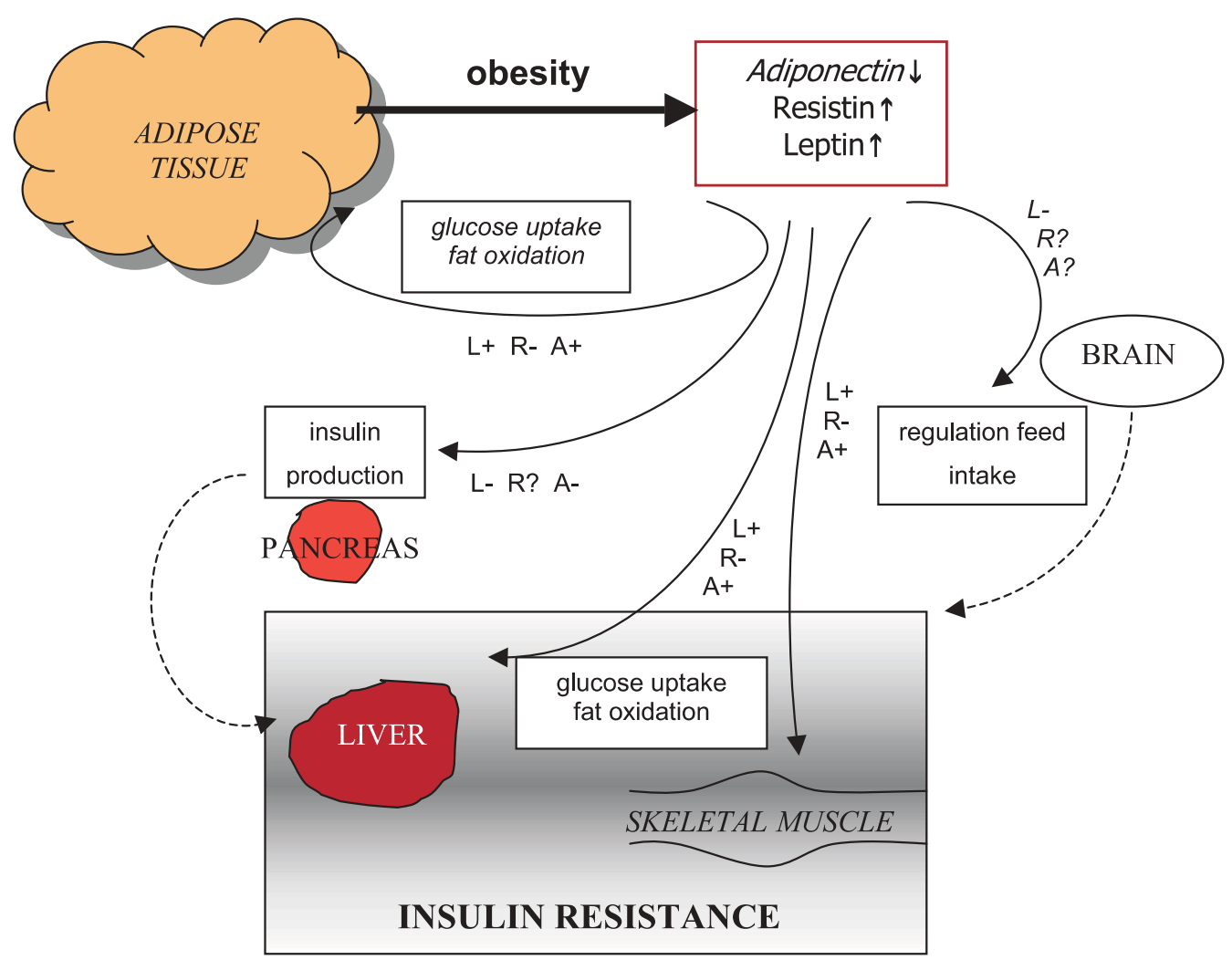

Figure 1 The potential interactions between adipokines and energy homeostasis. Expanded adipose tissue with obesity generally relates to an increase $(\uparrow)$ in leptin $(\mathrm{L})$ and resistin $(\mathrm{R})$ production, and a decrease $(\downarrow)$ in adiponectin $(\mathrm{A})$ production, to stimulate $(+)$, inhibit $(-)$ or have an as yet unknown (?) effect on energy metabolism. The potential interactions between these adipokines and the adipose tissue, skeletal muscle, liver and pancreas in obesity may have direct effects (solid arrows) and indirect effects (dashed arrows) on energy homeostasis.

region recently mapped as a susceptibility locus for type II diabetes and adiposity (Kissebah et al. 2000, Vionnet et al. 2000), and is thought to potentially link obesity to insulin resistance. Receptors for adiponectin, AdipoR1 and AdipoR2, were discovered recently in mice (Yamauchi et al. 2003) and a third receptor, t-cadherin, has also been identified, although the tissue distribution and functional significance of the latter remain to be elucidated (Hug et al. 2004).

Adiponectin functions as an insulin sensitising agent by reducing hepatic glucose production and enhancing insulin action in the liver (Berg et al. 2001, Combs et al. 2001). Furthermore, adiponectin reduces the activity of gluconeogenic enzymes phosphoenolpyruvate carboxykinase (PEPCK), glucose-6-phophatase (G6Pase), and reduces fatty acid oxidation in the liver (Combs et al. 2001, Yamauchi et al. 2002). A direct effect on insulin production is yet to be determined, however AdipoR1 are expressed in islets cells of the pancreas (Kharroubi et al. 2003) and adiponectin treatment of in vitro cultured islet cells from normal and high-fat fed rats, showed a differential response in insulin production suggesting an alternative role in insulin resistant states (Winzell et al. 2004). Adiponectin increases fatty acid oxidation in the liver, via a reduction in CD36 expression, reducing fatty-acid influx and liver triglycerides (Yamauchi et al. 2001). In skeletal muscle a reduction of triglyceride accumulation involves increased expression of proteins that transport lipids (CD36), fuel oxidation (acyl-CoA oxidase) and energy dissipation (uncoupling protein 2; UCP2) (Fruebis et al. 2001, Yamauchi et al. 2001). Although not completely defined, post-receptor signalling involving AMPK and downstream acetyl-CoA carboxylase (ACC), p38 mitogenactivated protein kinase (MAPK) and PPAR- $\alpha$ is described in skeletal muscle, liver and adipocytes (Tomas et al. 2002, Yamauchi et al. 2002, Wu et al. 2003, Yamauchi et al. 2003) and are thought to regulate glucose and lipid metabolism.

A transgenic mouse model generating a $2-3$ fold elevation of circulating adiponectin levels improved hepatic insulin sensitivity (Combs et al. 2004), although studies using adiponectin knock-out models are yet to demonstrate a clear relationship with glucose homeostasis, under various control and dietary treatments (Kubota et al. 2002, Ma et al. 2002, Maeda et al. 2002).

\section{Resistin}

The discovery of resistin (also known as FIZZ3 and adipocyte specific secretory factor; ADSF) was concurrent in three separate groups, focusing on aspects of lung 
inflammation (Holcomb et al. 2000), adipocyte differentiation (Kim et al. 2001) and screening targets of the insulin sensitising drug thiazolidinedione (Steppan et al. 2001). Despite the initial promise of resistin as the link between obesity and diabetes (Steppan et al. 2001), the discovery of low inter-species sequence homology (Gerstmayer et al. 2003), different chromosomal location of the gene between species (pig; Cepica et al. 2002, rat; Lin et al. 2003, bovine; Komatsu et al. 2003, Otieno et al. 2005) and differing sites of synthesis between species (Kim et al. 2001, Nagaev \& Smith 2001, Savage et al. 2001, Steppan et al. 2001, McTernan et al. 2002, Fain et al. 2003, Patel et al. 2003), have resulted in some confusion in relation to resistins role in the development of obesity and insulin resistance. The majority of studies investigating a wider metabolic role of resistin is limited to rodents and humans, but data should be interpreted with caution when comparing these models and when extrapolating to other species.

In rodents resistin is abundantly expressed in adipose tissue and has been linked to reduced insulin tolerance, via increased hepatic glucose production through increased hepatic gluconeogenic enzymes PEPCK and G6Pase, and decreased AMPK activity (Rajala et al. 2003, Banerjee et al. 2004, Muse et al. 2004). Furthermore, resistin decreases glucose uptake by adipocytes (Steppan et al. 2001) and skeletal muscle (Moon et al. 2003, Pravenec et al. 2003) indicating that muscle, adipose tissue and liver contribute to impaired glucose sensitivity in rodents. In contrast, resistin mRNA expression in human adipocytes is comparably low (Nagaev \& Smith 2001, Savage et al. 2001, McTernan et al. 2002). Although resistin altered proliferation of cultured human adipocytes (Ort et al. 2005), it did not affect glucose uptake or Akt phosphorylation (Ort et al. 2005), which raises the possibility that in humans resistin is not directly involved in glucose homeostasis in adipocytes. Resistin is however highly expressed in macrophages and monocytes (Savage et al. 2001, Patel et al. 2003) suggesting it may influence insulin resistance via effects on inflammation. Therefore, in rodents the direct role of resistin in obesity and glucose utilisation is more apparent than in humans, where it may be related to the functioning of adipose tissue rather than insulin resistance per se.

\section{Adipokines and fertility}

Evidence supporting a link between adipose-secreted adipokines and female fertility may be considered at four levels (Fig. 2) and is discussed here in this context; a) central effects on the hypothalamus and pituitary, b) peripheral effects on the ovary and reproductive tract, c) direct effects on the oocyte and the embryo and d) effects during pregnancy. Table 2 summarises our knowledge to date concerning the influence of sex hormones, puberty and the reproductive disorder poly-cystic ovary syndrome
(PCOS) on levels of leptin, adiponectin and resistin, in tissues and in circulation.

\section{Fertility of transgenic and knock-out models}

The first experiments to raise interest in adipokines and reproduction involved the reinstatement of fertility of otherwise infertile ob/ob mice (which do not produce leptin), with the exogenous administration of leptin to both female (Chehab et al. 1996) and male (Mounzih et al. 1997) mice. Transgenic female mice expressing $2-3$ times the normal circulating levels of adiponectin are infertile (Combs et al. 2004) although the extent and nature of this fertility defect are not defined. Furthermore, various studies whereby adiponectin levels are ablated fail to describe any adverse fertility effects (Kubota et al. 2002, Ma et al. 2002, Maeda et al. 2002). The manipulation of resistin expression to increase or decrease protein levels in adipose tissue or liver, had no reported effect on fertility (Pravenec et al., 2003, Banerjee et al. 2004, Rangwala et al. 2004). Thus a comprehensive study of any infertility or sub-fertility in the adiponectin or resistin modified models are yet to be completed but are warranted given the alignment of physiological functions of both adipokines with leptin.

\section{Adipokine role in maturation and action of the hypothalamus and pituitary}

Serum levels of leptin at puberty are generally increased in mice (Chehab et al. 1997), pigs (Qian et al. 1999) and cattle (Garcia et al. 2002), and are positively correlated to age of first period in women (Matkovic et al. 1997). Although there are some exceptions (Bronson 2001, Cheung et al. 2001) it is generally hypothesised that an elevation in leptin to a threshold level permits the activation of the hypothalamic-pituitary axis and the onset of puberty. Similar to serum levels of leptin, the expression of resistin in adipose tissue and the pituitary increased peri-pubertally in rodents (Morash et al. 2002, Nogueiras et al. 2003a). Plasma adiponectin levels in mice increase at puberty (Combs et al. 2003) in contrast to declining serum levels in boys and girls throughout puberty (Bottner et al. 2004). The mechanism responsible for the increase in mice appears to be common for both sexes, as the removal of the gonads prior to puberty did not affect its timing (Combs et al. 2003). Therefore a role for adipokines at the central level of the hypothalamus and pituitary in the regulation of pubertal development and subsequent cyclic female fertility is likely, and is explored herein.

Leptin's central role in fertility influences $\mathrm{GnRH}$ secretion by the hypothalamus and the pituitary secretion of gonadotrophins luteinizing hormone $(\mathrm{LH})$ and folliclestimulating hormone (FSH) (Nagatani et al. 1998). The availability of nutrients influences this central effect, with fasting causing a decrease in leptin and LH levels in numerous species and the restoration of $\mathrm{LH}$ pulsatility 


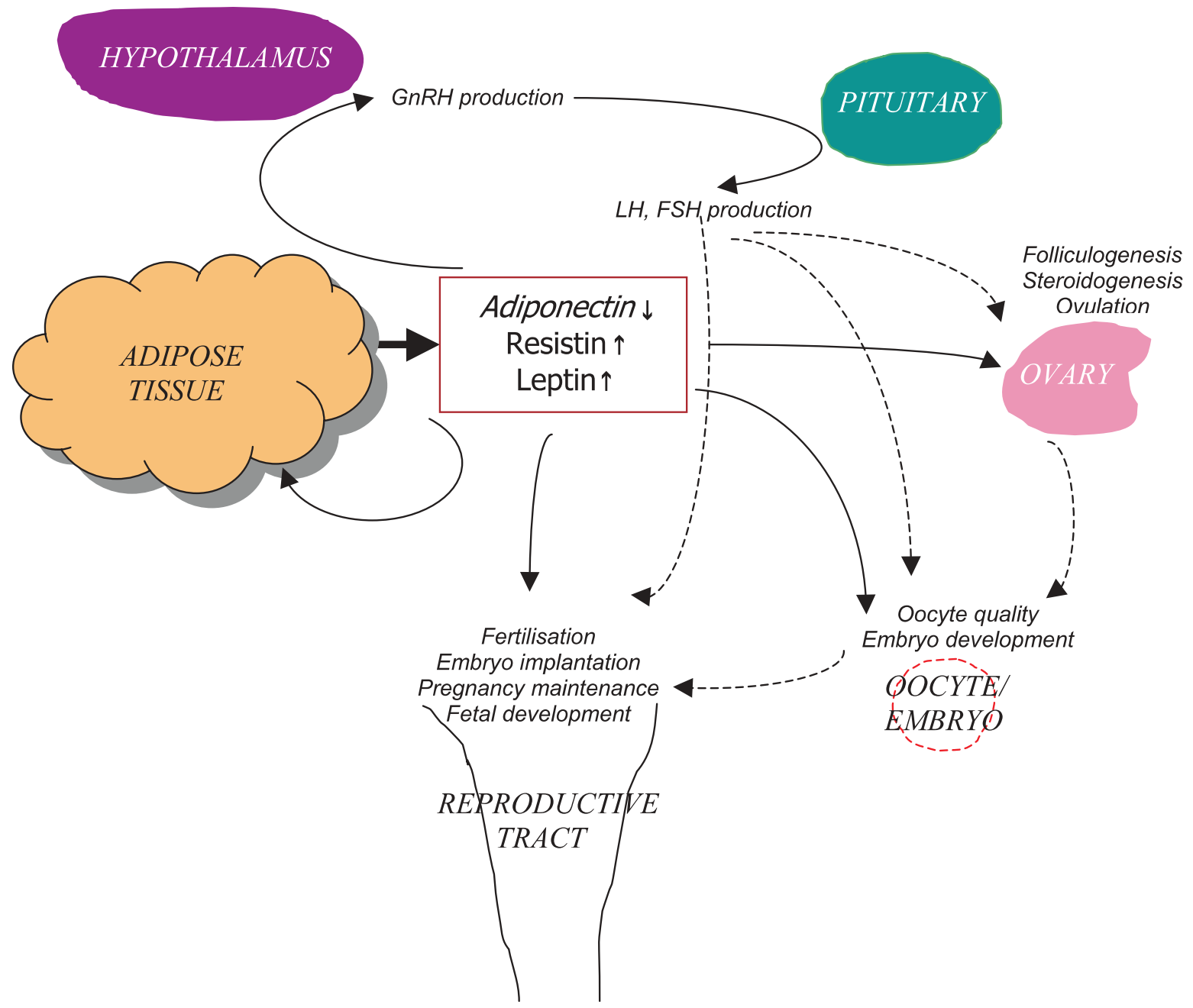

Figure 2 The potential interactions between adipokines and female reproduction. Expanded adipose tissue with obesity leads to an increase ( $\uparrow$ ) in leptin and resistin production, and a decrease $(\downarrow)$ in adiponectin production. The potential interactions between these adipokines and the hypothalamus, pituitary, ovary, oocyte and embryo, and the female reproductive tract may have direct effects (solid arrows) and indirect effects (dashed arrows) on female reproduction.

following leptin administration (Ahima et al. 1996, Amstalden et al. 2000, Henry et al. 2001, Whisnant \& Harrell 2002). In the well-fed ruminant (Henry et al. 2001, Amstalden et al. 2002) and pig (Barb et al. 2004), leptin administration failed to alter $\mathrm{LH}$ secretion, in contrast to data in well-fed rodents. Experiments conducted in vitro using tissue from well-fed rodents and pigs, showed that leptin stimulated the release of gonadotrophin-releasing hormone $(\mathrm{GnRH})$ from hypothalamic explants and cells (Yu et al. 1997, Barb 1999, Woller et al. 2001) and stimulated $\mathrm{LH}$ and $\mathrm{FSH}$ release from adenohypophyseal explants and cells (Yu et al. 1997, Barb 1999, De Biasi et al. 2001, Ogura et al. 2001), suggesting both the hypothalamus and the pituitary as central sites of leptin action. However, similar experiments using cells and explants from well-fed cattle showed no change in GnRH or gonadotrophin secretion in response to the administration of leptin (Amstalden et al. 2005). Thus, the central role of leptin and the interactions between species and nutritional status remain to be explored further but suggest the possible development of central leptin resistance in ruminants when energy balance is positive or neutral (Amstalden et al. 2005).

Any prediction of a central role for adiponectin or resistin, interacting with $\mathrm{GnRH}$ and gonadotrophin production, or regulating energy metabolism is premature at this stage. However, a small number of studies have investigated expression and activity of these adipokines in cells from the hypothalamus and the pituitary. Studies using cultured rat hypothalamic neurons, failed to show a stimulatory effect of adiponectin on the production of various neurotransmitters involved in central energy metabolism, and this was in contrast to the enhanced production in response to resistin (Brunetti et al. 2004). Resistin mRNA expression has been localised to the pituitary and the hypothalamus, but expression of adiponectin by these 
Table 2 The influence of sex hormones, puberty and the reproductive disorder poly-cystic ovary syndrome (PCOS) on levels of leptin, adiponectin and resistin, in tissues and in circulation.

\begin{tabular}{|c|c|c|c|c|c|c|c|c|c|}
\hline & \multicolumn{3}{|c|}{ Adiponectin } & \multicolumn{3}{|c|}{ Resistin } & \multicolumn{3}{|c|}{ Leptin } \\
\hline & $\begin{array}{l}\mathrm{mRNA} \text { and/or } \\
\text { protein }\end{array}$ & $\begin{array}{l}\text { Circulating } \\
\text { levels }\end{array}$ & Authors & $\begin{array}{l}\text { mRNA and/or } \\
\text { protein }\end{array}$ & $\begin{array}{l}\text { Circulating } \\
\text { levels }\end{array}$ & Authors & $\begin{array}{l}\mathrm{mRNA} \text { and/or } \\
\text { protein }\end{array}$ & $\begin{array}{l}\text { Circulating } \\
\text { levels }\end{array}$ & Authors \\
\hline \multirow[t]{3}{*}{$\begin{array}{l}\text { Female vs } \\
\text { males }\end{array}$} & & $\uparrow$ & Arita et al. 1999 & $\downarrow$ & & $\begin{array}{l}\text { Nogueiras et al. } \\
2003 a, b\end{array}$ & & $\uparrow$ & Armellini et al. 2000 \\
\hline & & $\uparrow$ & Huang et al. 2004 & & $\uparrow$ & $\begin{array}{c}\text { Yannakoulia et al. } \\
2003\end{array}$ & $\uparrow$ & & Gui et al. 2004 \\
\hline & $\uparrow$ & $\uparrow$ & $\begin{array}{l}\text { Combs et al. } 2003 \\
\text { Gui et al. } 2004\end{array}$ & $\uparrow$ & & Gui et al. 2004 & & $\uparrow$ & $\begin{array}{c}\text { Degawa-Yamauchi et al. } \\
2003 a\end{array}$ \\
\hline Puberty & $\uparrow$ & $\uparrow$ & $\begin{array}{l}\text { Combs et al. } 2003 \\
\text { Bottner et al. } 2004\end{array}$ & $\begin{array}{l}\uparrow \\
\uparrow \\
\uparrow\end{array}$ & & $\begin{array}{c}\text { Morash et al. } 2002 \\
\text { Brown et al. } 2005 \\
\text { Nogueiras et al. } \\
2003 a\end{array}$ & & $\begin{array}{l}\uparrow \\
\uparrow \\
\uparrow\end{array}$ & $\begin{array}{c}\text { Chehab et al. } 1997 \\
\text { Garcia et al. } 2002 \\
\text { Qian et al. } 1999\end{array}$ \\
\hline \multirow[t]{2}{*}{ Oestrogen } & & $\downarrow$ & Combs et al. 2003 & $\downarrow$ & & Huang et al. 2005 & $\uparrow$ & $\uparrow$ & $\begin{array}{l}\text { Matkovic et al. } 1997 \\
\text { Kristensen et al. } 1999\end{array}$ \\
\hline & $\uparrow$ & - & Gui et al. 2004 & $\downarrow$ & - & Gui et al. 2004 & $\uparrow$ & - & $\begin{array}{c}\text { Gui et al. } 2004 \\
\text { Murakami et al. } 1995\end{array}$ \\
\hline \multirow[t]{2}{*}{ Androgens } & - & $\bar{\downarrow}$ & $\begin{array}{c}\text { Gui et al. } 2004 \\
\text { Nishizawa et al. } 2002\end{array}$ & $\stackrel{\uparrow}{-}$ & - & $\begin{array}{l}\text { Ling et al. } 2001 \\
\text { Gui et al. } 2004\end{array}$ & $\begin{array}{l}\uparrow \\
-\end{array}$ & $\uparrow$ & $\begin{array}{l}\text { Gui et al. } 2004 \\
\text { Kristensen et al. } 1999\end{array}$ \\
\hline & & $\stackrel{\downarrow}{\downarrow}$ & $\begin{array}{l}\text { Bottner et al. } 2004 \\
\text { Page et al. } 2005\end{array}$ & & & & - & & Murakami et al. 1995 \\
\hline \multirow{5}{*}{$\begin{array}{l}\text { PCOS vs } \\
\text { normalt }\end{array}$} & & - & Orio et al. 2003 & $\uparrow$ & & Seow et al. 2004 & & - & Carmina et al. 2005 \\
\hline & & $\downarrow$ & Carmina et al. 2005 & & $\uparrow$ & Carmina et al. 2005 & & - & Chapman et al. 1997 \\
\hline & & $\downarrow$ & Sieminska et al. 2004 & & - & Seow et al. 2005 & & - & Remsberg et al. 2002 \\
\hline & & $\downarrow$ & $\begin{array}{c}\text { Sepilian \& Nagamani } \\
2005\end{array}$ & & $\uparrow$ & Munir et al. 2005 & & $\uparrow$ & Vicennati et al. 1998 \\
\hline & & & & & & & & $\uparrow$ & Brzechffa et al. 1996 \\
\hline
\end{tabular}

$\uparrow=$ increased levels; $-=$ decreased levels; - = no change in levels of adipokines.

tPCOS and normal ovulating women were BMI and age matched. 
tissues has not yet been reported. Resistin expression levels were low in mouse pituitary at birth, increasing to peak levels at puberty, in contrast to the consistent expression by cells of the hypothalamus throughout development (Morash et al. 2002). The changes in expression by the pituitary around the time of puberty require signals from the hypothalamus, as was demonstrated by an absence of resistin expression in peri-pubertal mice with ablated hypothalamic cells (Morash et al. 2002). Furthermore, the reduction in pituitary levels of resistin in obese mice compared with control mice (Morash et al. 2004) and the co-localisation of resistin protein in rodent hypothalamus with neurons involved in feeding behaviour (Wilkinson et al. 2005) give weight to a link between resistin and the central control of feeding and obesity. Although a report in male rodents suggests that expression of resistin in the testis is regulated by the pituitary hormones LH and FSH (Nogueiras et al. 2004), like studies in female reproductive tissue are yet to be documented. Further exploration of resistin's role in central energy metabolism, and gonadotrophin production will undoubtedly provide insight into its function in puberty attainment and the regulation of female fertility.

The central expression of adiponectin and its receptors in the hypothalamus and pituitary are yet to be completely explored but studies in mice suggest unaltered feed intake by mice lacking (Kubota et al. 2002, Maeda et al. 2002) or mice over-expressing (Combs et al. 2004) adiponectin protein. In addition, both the central and peripheral administration of adiponectin protein failed to influence feed intake of obese mice (Masaki et al. 2003). This was in contrast to similar studies of leptin, whereby its central function via the hypothalamus resulted in reduced intake of food in well-fed ruminants (Henry et al. 1999, Morrison et al. 2001), pigs (Barb et al. 1998, Ramsay et al. 2004, Weber \& Spurlock 2004) and rodents (Pelleymounter et al. 1995, Mistry et al. 1997). As discussed in the Adiponectin section above, one known pathway through which adiponectin functions in peripheral tissues is via the cellular nutrient- sensor AMPK. Leptin too operates via this pathway, and in the hypothalamus it inhibits AMPK activation causing a reduction in food intake (Andersson et al. 2004). In contrast to this central action, leptin stimulates AMPK activation in skeletal muscle, (Minokoshi et al. 2002), a stimulation mirrored by adiponectin in various peripheral tissues (Tomas et al. 2002, Yamauchi et al. 2002, Wu et al. 2003). Given that both adipokines function to stimulate AMPK in peripheral tissues, it is conceivable that adiponectin in fact influences energy utilisation centrally via the same AMPK mechanism as leptin in the hypothalamus.

The underlying cause of reduced fertility in models of diet-induced obesity are important because unlike the $\mathrm{ob} / \mathrm{ob}$ and $\mathrm{db} / \mathrm{db}$ monogenic mutations researched extensively to date, human and rodent obesity results from complex interactions between genetics and the environment. Such obesity is often characterised by high circulat- ing levels of leptin and increased leptin resistance (Halaas et al. 1997, Van Heek et al. 1997, Heymsfield et al. 1999, Hukshorn et al. 2000). A report by Tortoriello and colleagues discussed the development of leptin resistance and acquired obesity in a diet-induced animal model of obesity, with a rare and specific focus on fertility (Tortoriello et al. 2004). Diet-induced obesity exerted a greater effect on fertility in female mice compared with males. This was linked more closely to hyperleptinemia than hyperinsulinemia, and was overcome with $\mathrm{GnRH}$ stimulation, suggesting causes other than ovarian or uterine dysfunction for the infertility observed in this model (Tortoriello et al. 2004). Despite previous studies of dietinduced obesity in rodents failing to agree with regards to altered hypothalamic leptin receptor expression (El-Haschimi et al. 2000, Martin et al. 2000), the cause of infertility in this study was related to decreased leptin receptor expression and increased neuropeptide-Y levels in the hypothalamus, that is, reduced central leptin sensitivity and decreased GnRH pulsatility.

\section{Adipokine role in the ovary and reproductive tissue}

In general, the effects of adipokines on the process of ovulation, ovarian steroidogenesis and the maintenance of pregnancy have received limited attention. Reduced ovulation rate in in vivo experiments in which leptin was administered to intact rats, and in vitro culture studies of whole ovaries perfused with leptin, indicate a direct role for leptin in the ovulation process, independent of any change in steroid production (Duggal et al. 2000). In addition a recent report in mice that were deficient in $\mathrm{GnRH}$ indicated an effect of leptin on ovulation independent of $\mathrm{GnRH}$ and $\mathrm{LH}$ that involved a local function in the ovary, such as induction of ADAMTS-1 (a disintegrin and metalloproteinase with a thrombospondin-like motif), although other undefined hypothalamic pathways could not be excluded (Barkan et al. 2005). As yet, there are no similar mechanistic studies of the function of resistin or adiponectin in the process of ovulation. Furthermore, data concerning serum and local levels of adipokines in the ovary, with regards to the anovulatory disorder in humans poly-cystic ovary syndrome (PCOS) are not always clear, as is summarised in Table 2. Therefore, this remains as a significant area for future investigation.

The fat-soluble steroid hormones are produced by ovary cell steroidogenesis, and the adipocyte derived adipokines may have a localised function in this process. Expression of both leptin mRNA and protein in granulosa and theca cells, support this possibility (Cioffi et al. 1997, Karlsson et al. 1997). Leptin influences steroidogenesis in isolated ovarian cells by modulating the metabolic actions of insulin and IGF-I and the stimulatory actions of gonadotrophins in cattle (Spicer \& Francisco 1997, 1998, Spicer et al. 2000), pig (Gregoraszczuk et al. 2003, 2004), rodent (Zachow \& Magoffin 1997, Duggal et al. 2002) and human (Agarwal et al. 1999, Guo et al. 2001, Tsai et al. 
2002). Furthermore in humans, blood leptin levels correlate closely with those of progesterone throughout the menstrual cycle, and with both oestradiol and human choriogonadotrophin (hCG) throughout pregnancy (Hardie et al. 1997).

A role for adiponectin in ovarian steroidogenesis is yet to be described but an interaction is likely given the negative effects of testosterone on circulating adiponectin in humans (Lanfranco et al. 2004, Page et al. 2005) and mice (Nishizawa et al. 2002). Such an interaction has been demonstrated by resistin, which has stimulatory effects on testosterone production by cultured human theca cells that synergise with insulin (Munir et al. 2005). Furthermore, resistin dose-dependently increased the production of testosterone by cultured rat testis (Nogueiras et al. 2004), and the adrenal androgen dehydroepiandrosterone (DHEA) reduced mRNA expression of resistin in adipose tissue taken from rats (Kochan \& Karbowska 2004).

Studies of the expression and activity of adipokines in the oviduct and endometrium are limited to leptin. Leptin and its receptors (mRNA and protein) are expressed in the oviduct (Kawamura et al. 2002, Craig et al. 2005) and the endometrium (Gonzalez et al. 2000, Kawamura et al. 2002, Cerevo et al. 2005), suggesting possible involvement in endometrial receptivity for the developing embryo.

\section{Adipokine role in oocyte quality and embryo development}

The discovery of leptin expression in mature human oocytes, combined with a post-ovulatory surge in its circulating levels (Cioffi et al. 1997), indicate that leptin may also effect maturation of the oocyte and influence early embryo development. Studies in humans, rodents and pigs have shown mRNA and/or protein expression for the leptin receptors in oocytes and developing early embryos (Kawamura et al. 2002, Cerevo et al. 2005, Craig et al. 2005), and leptin expression itself in the rodent blastocyst (Cioffi et al. 1997, Ryan et al. 2002), with some variability related to species. Some conflict surrounds the nature of leptin's direct role in oocyte maturation, in different rodent species and between cultured whole follicles and oocytes (Ryan et al. 2002, Duggal et al. 2002, Swain et al. 2004). There are also conflicting reports concerning whether leptin enhances (Kawamura et al. 2002) or impedes (Fedorcsak \& Storeng 2003) development of the pre-implantation mouse embryo but in the pig, leptin improves oocyte nuclear maturation via the MAPK pathway and increases embryo development in vitro (Craig et al. 2004).

Adiponectin receptors R1 and R2 are weakly expressed in the pig ovary (Lord et al. 2005), and to date this is the only documentation of expression in ovarian tissue or oocytes. Given that AMPK activity has been described in oocytes, coincident with germinal vesicle breakdown and induction of meiosis in preparation for fertilisation
(Downs et al. 2002), adiponectin may be involved in regulation of oocyte nutrient-sensing via the AMPK pathway. There have been no reports to date of resistin expression in the ovary, oocyte or embryo of any species. This highlights a basic gap in our knowledge of how adipokines may regulate nutrient use for the developing oocyte and embryo.

\section{Adipokines in pregnancy}

Pregnancy invokes a large shift in maternal metabolism, which enables the provision of appropriate nutrients to the developing fetus as well as providing for physiological maintenance of the mother and preparation for lactation. Investigation of adipokines such as leptin, adiponectin and resistin in this metabolic shift is not a focus of this review but is an important aspect of fertility reviewed most notably for the role of leptin (Sagawa et al. 2002). The developing placenta expresses both leptin and its receptor (Masuzaki et al. 1997, Senaris et al. 1997) and placental resistin production has been reported recently in humans (Yura et al. 2003). Resistin serum and placental levels increases as pregnancy progresses (Yura et al. 2003), which is in contrast to levels of leptin (Masuzaki et al. 1997). These levels correlate with the state of reduced insulin sensitivity often developed in the latter stages of pregnancy, thus contributing to successful development of the fetus (Yura et al. 2003). Adiponectin and its receptors (R1 and R2) have also recently been localised to the placenta of humans and rats (Caminos et al. 2005), and the uterus of pigs (Lord et al. 2005). In the rat, placental expression of adiponectin mRNA increased during pregnancy and decreased in response to feed restriction, whereas the AdipoR2 receptor expression decreased during pregnancy but remained unchanged during undernutrition (Caminos et al. 2005), adding support for numerous roles of these adipokines in the maintenance of a normal pregnancy.

\section{Conclusion}

The adipokines leptin, adiponectin and resistin produced by adipose tissue and altered with obesity, clearly influence energy homeostasis and undoubtedly affect female fertility. Leptin alters $\mathrm{GnRH}$ and gonadotrophin production, and has a complexity of roles in the functioning of the ovary and endometrium, as well as in embryo development. The expansive influence on female fertility uncovered by leptin research has potential implications for other adipokines, which themselves operate similarly to regulate energy metabolism. The paucity of information implicating a role for adiponectin and resistin at any central or local level of female reproduction makes any firm statements at this time precarious in nature. That aside, current limited data implicate resistin in placental and ovarian function, and its localisation in the brain, suggest possible peripheral and central effects in the control of 
energy metabolism and fertility. Evidence to date does not support a central role for adiponectin but recently the expression of its receptors in the ovary and its signalling via the AMPK nutrient-sensing pathway in other peripheral tissues, indicate future avenues for adiponectin research. Finally, amongst all the unknowns and anomalies regarding the biological activities of these adipokines in female fertility, there is but one point of clarity-adipokine research in relation to reproduction is very fertile ground for future exploration.

\section{Acknowledgements}

The authors declare that there is no conflict of interest that would prejudice the impartiality of this scientific work.

\section{References}

Agarwal SK, Vogel K, Weitsman SR \& Magoffin DA 1999 Leptin antagonizes the insulin-like growth factor-I augmentation of steroidogenesis in granulosa and theca cells of the human ovary. Journal of Clinical Endocrinology and Metabolism 84 1072-1076.

Ahima RS, Prabakaran D, Mantzoros C, Qu D, Lowell B, MaratosFlier E \& Flier JS 1996 Role of leptin in the neuroendocrine response to fasting. Nature 382 250-252.

Amstalden M, Garcia MR, Williams SW, Stanko RL, Nizielski SE, Morrison CD, Keisler DH \& Williams GL 2000 Leptin gene expression, circulating leptin, and luteinizing hormone pulsatility are acutely responsive to short-term fasting in prepubertal heifers: relationships to circulating insulin and insulin-like growth factor I(1). Biology of Reproduction 63 127-133.

Amstalden M, Garcia MR, Stanko RL, Nizielski SE, Morrison CD, Keisler DH \& Williams GL 2002 Central infusion of recombinant ovine leptin normalizes plasma insulin and stimulates a novel hypersecretion of luteinizing hormone after short-term fasting in mature beef cows. Biology of Reproduction 66 1555-1561.

Amstalden M, Harms PG, Welsh TH Jr, Randel RD \& Williams GL 2005 Effects of leptin on gonadotropin-releasing hormone release from hypothalamic-infundibular explants and gonadotropin release from adenohypophyseal primary cell cultures: further evidence that fully nourished cattle are resistant to leptin. Animal Reproductive Science 85 41-52.

Andersson U, Filipsson K, Abbott CR, Woods A, Smith K, Bloom SR, Carling D \& Small CJ 2004 AMP-activated protein kinase plays a role in the control of food intake. Journal of Biological Chemistry 279 12005-12008.

Arita Y, Kihara S, Ouchi N, Takahashi M, Maeda K, Miyagawa J, Hotta K, Shimomura I, Nakamura T, Miyaoka K, Kuriyama H, Nishida M, Yamashita S, Okubo K, Matsubara K, Muraguchi M, Ohmoto Y, Funahashi T \& Matsuzawa Y 1999 Paradoxical decrease of an adipose-specific protein, adiponectin, in obesity. Biochemical and Biophysical Research Communications 257 79-83.

Armellini F, Zamboni M \& Bosello O 2000 Hormones and body composition in humans: clinical studies. International Journal of Obesity and Related Metabolic Disorders 24 Suppl 2 S18-S21.

Azuma K, Katsukawa F, Oguchi S, Murata M, Yamazaki H, Shimada A \& Saruta T 2003 Correlation between serum resistin level and adiposity in obese individuals. Obesity Research 11 997-1001.

Banerjee RR, Rangwala SM, Shapiro JS, Rich AS, Rhoades B, Qi Y, Wang J, Rajala MW, Pocai A, Scherer PE, Steppan CM, Ahima RS, Obici S, Rossetti L \& Lazar MA 2004 Regulation of fasted blood glucose by resistin. Science 303 1195-1198.

Barb CR, Yan X, Azain MJ, Kraeling RR, Rampacek GB \& Ramsay TG 1998 Recombinant porcine leptin reduces feed intake and stimulates growth hormone secretion in swine. Domestic Animal Endocrinology 15 77-86.

Barb CR 1999 The brain-pituitary-adipocyte axis: role of leptin in modulating neuroendocrine function. Journal of Animal Science $771249-1257$.

Barb CR, Barrett JB \& Kraeling RR 2004 Role of leptin in modulating the hypothalamic-pituitary axis and luteinizing hormone secretion in the prepuberal gilt. Domestic Animal Endocrinology 26 201-214.

Barkan D, Hurgin V, Dekel N, Amsterdam A \& Rubinstein M 2005 Leptin induces ovulation in GnRH-deficient mice. FASEB 19 133-135.

Bendinelli P, Maroni P, Pecori Giraldi F \& Piccoletti R 2000 Leptin activates Stat3, Stat1 and AP-1 in mouse adipose tissue. Molecular and Cellular Endocrinology 168 11-20.

Berg AH, Combs TP, Du X \& Brownlee M 2001 Scherer PE, The adipocyte-secreted protein Acrp30 enhances hepatic insulin action. Nature Medicine 7 947-953.

Bjorbaek C \& Kahn BB 2004 Leptin signaling in the central nervous system and the periphery. Recent Progress in Hormone Research $59305-331$.

Bottner A, Kratzsch J, Muller G, Kapellen TM, Bluher S, Keller E, Bluher M \& Kiess W 2004 Gender differences of adiponectin levels develop during the progression of puberty and are related to serum androgen levels. Journal of Clinical Endocrinology and Metabolism 89 4053-4061.

Bronson FH 2001 Puberty in female mice is not associated with increases in either body fat or leptin. Endocrinology $\mathbf{1 4 2}$ $4758-4761$.

Brown R, Wiesner G, Ur E \& Wilkinson M 2005 Pituitary Resistin Gene Expression Is Upregulated in vitro and in vivo by Dexamethasone but Is Unaffected by Rosiglitazone. Neuroendocrinology 81 41-48.

Brunetti L, Orlando G, Recinella L, Michelotto B, Ferrante C \& Vacca M 2004 Resistin, but not adiponectin, inhibits dopamine and norepinephrine release in the hypothalamus. European Journal of Pharmacology 493 41-44.

Brzechffa PR, Jakimiuk AJ, Agarwal SK, Weitsman SR, Buyalos RP \& Magoffin DA 1996 Serum immunoreactive leptin concentrations in women with polycystic ovary syndrome. Journal of Clinical Endocrinology and Metabolism 81 4166-4169.

Bullo M, Salas-Salvado J \& Garcia-Lorda P 2005 Adiponectin expression adipose tissue lipolytic activity in lean and obese women. Obesity Surgery 15 382-386.

Caminos JE, Nogueiras R, Gallego R, Bravo S, Tovar S, Garcia-Caballero T, Casanueva FF \& Dieguez C 2005 Expression and Regulation of Adiponectin and Receptor in Human and Rat Placenta. Journal of Clinical Endocrinology and Metabolism 90 4276-4286.

Carmina E, Orio F, Palomba S, Cascella T, Longo RA, Colao AM, Lombardi G \& Lobo RA 2005 Evidence for altered adipocyte function in polycystic ovary syndrome. European Journal of Endocrinology 152 389-394.

Cepica S, Rohrer GA, Masopust M, Kubickova S, Musilova P \& Rubes J 2002 Partial cloning, cytogenetic and linkage mapping of the porcine resistin (RSTN) gene. Animal Genetics 33 $381-383$.

Cervero A, Horcajadas JA, Dominguez F, Pellicer A \& Simon C 2005 Leptin system in embryo development and implantation: a protein in search of a function. Reproductive Biomedicine Online 10 217-223.

Chapman IM, Wittert GA \& Norman RJ 1997 Circulating leptin concentrations in polycystic ovary syndrome: relation to anthropometric and metabolic parameters. Clinical Endocrinology (Oxf) $\mathbf{4 6}$ 175-181.

Chehab FF, Lim ME \& Lu R 1996 Correction of the sterility defect in homozygous obese female mice by treatment with the human recombinant leptin. Nature Genetics 12 318-320.

Chehab FF, Mounzih K, Lu R \& Lim ME 1997 Early onset of reproductive function in normal female mice treated with leptin. Science 275 88-90. 
Chen XD, Lei T, Xia T, Gan L \& Yang ZQ 2004 Increased expression of resistin and tumour necrosis factor-alpha in pig adipose tissue as well as effect of feeding treatment on resistin and cAMP pathway. Diabetes Obesity and Metabolism 6 271-279.

Cheung CC, Clifton DK \& Steiner RA 1997 Proopiomelanocortin neurons are direct targets for leptin in the hypothalamus. Endocrinology 138 4489-4492.

Cheung CC, Thornton JE, Nurani SD, Clifton DK \& Steiner RA 2001 A reassessment of leptin's role in triggering the onset of puberty in the rat and mouse. Neuroendocrinology 74 12-21.

Cioffi JA, Van Blerkom J, Antczak M, Shafer A, Wittmer S \& Snodgrass HR 1997 The expression of leptin and its receptors in pre-ovulatory human follicles. Molecular Human Reproduction 3 467-472.

Cnop M, Havel PJ, Utzschneider KM, Carr DB, Sinha MK, Boyko EJ, Retzlaff BM, Knopp RH, Brunzell JD \& Kahn SE 2003 Relationship of adiponectin to body fat distribution, insulin sensitivity and plasma lipoproteins: evidence for independent roles of age and sex. Diabetologia 46 459-469.

Cohen P, Zhao C, Cai X, Montez JM, Rohani SC, Feinstein P, Mombaerts P \& Friedman JM 2001 Selective deletion of leptin receptor in neurons leads to obesity. Journal of Clinical Investigation $\mathbf{1 0 8}$ $1113-1121$.

Combs TP, Berg AH, Obici S, Scherer PE \& Rossetti L 2001 Endogenous glucose production is inhibited by the adipose-derived protein Acrp30. Journal of Clinical Investigation $\mathbf{1 0 8}$ $1875-1881$

Combs TP, Berg AH, Rajala MW, Klebanov S, lyengar P, JimenezChillaron JC, Patti ME, Klein SL, Weinstein RS \& Scherer PE 2003 Sexual differentiation, pregnancy, calorie restriction, and aging affect the adipocyte-specific secretory protein adiponectin. Diabetes 52 268-276.

Combs TP, Pajvani UB, Berg AH, Lin $\mathrm{Y}$, Jelicks LA, Laplante $M$, Nawrocki AR, Rajala MW, Parlow AF, Cheeseboro L, Ding YY, Russell RG, Lindemann D, Hartley A, Baker GR, Obici S, Deshaies Y, Ludgate M, Rossetti L \& Scherer PE 2004 A transgenic mouse with a deletion in the collagenous domain of adiponectin displays elevated circulating adiponectin and improved insulin sensitivity. Endocrinology 145 367-383.

Considine RV, Sinha MK, Heiman ML, Kriauciunas A, Stephens TW, Nyce MR, Ohannesian JP, Marco CC, McKee LJ, Bauer TL \& Caro JF 1996 Serum immunoreactive-leptin concentrations in normalweight and obese humans. New England Journal of Medicine 334 $292-295$.

Craig J, Zhu H, Dyce PW, Petrik J \& Li J 2004 Leptin enhances oocyte nuclear and cytoplasmic maturation via the mitogen-activated protein kinase pathway. Endocrinology $\mathbf{1 4 5}$ $5355-5363$

Craig JA, Zhu H, Dyce PW, Wen L \& Li J 2005 Leptin enhances porcine preimplantation embryo development in vitro. Molecular and Cellular Endocrinology 229 141-147.

Crosignani PG, Vegetti W, Colombo M \& Ragni G 2002 Resumption of fertility with diet in overweight women. Reproductive Biomedicine Online 5 60-64.

De Biasi SN, Apfelbaum LI \& Apfelbaum ME 2001 In vitro effect of leptin on $\mathrm{LH}$ release by anterior pituitary glands from female rats at the time of spontaneous and steroid-induced LH surge. European Journal of Endocrinology 145 659-665.

Degawa-Yamauchi M, Dilts JR, Bovenkerk JE, Saha C, Pratt JH \& Considine RV 2003a Lower serum adiponectin levels in AfricanAmerican boys. Obesity Research 11 1384-1390.

Degawa-Yamauchi M, Bovenkerk JE, Juliar BE, Watson W, Kerr K, Jones R, Zhu Q \& Considine RV 2003b Serum resistin (FIZZ3) protein is increased in obese humans. Journal of Clinical Endocrinology and Metabolism 88 5452-5455.

Diamond FB Jr, Cuthbertson D, Hanna S \& Eichler D 2004 Correlates of adiponectin and the leptin/adiponectin ratio in obese and non-obese children. Journal of Pediatric Endocrinology and Metabolism 17 1069-1075.
Downs SM, Hudson ER \& Hardie DG 2002 A potential role for AMPactivated protein kinase in meiotic induction in mouse oocytes. Developmental Biology 245 200-212.

Duggal PS, Van Der Hoek KH, Milner CR, Ryan NK, Armstrong DT, Magoffin DA \& Norman RJ 2000 The in vivo and in vitro effects of exogenous leptin on ovulation in the rat. Endocrinology $\mathbf{1 4 1}$ $1971-1976$

Duggal PS, Ryan NK, Van der Hoek KH, Ritter LJ, Armstrong DT, Magoffin DA \& Norman RJ 2002 Effects of leptin administration and feed restriction on thecal leucocytes in the preovulatory rat ovary and the effects of leptin on meiotic maturation, granulosa cell proliferation, steroid hormone and PGE2 release in cultured rat ovarian follicles. Reproduction 123 891-898.

Eckel RH, Grundy SM \& Zimmet PZ 2005 The metabolic syndrome. Lancet 365 1415-1428.

El-Haschimi K, Pierroz DD, Hileman SM, Bjorbaek C \& Flier JS 2000 Two defects contribute to hypothalamic leptin resistance in mice with diet-induced obesity. Journal of Clinical Investigation 105 1827-1832.

Fain JN, Cheema PS, Bahouth SW \& Lloyd Hiler M 2003 Resistin release by human adipose tissue explants in primary culture. Biochemical and Biophysical Research Communications 300 674-678.

Fedorcsak P \& Storeng R 2003 Effects of leptin and leukemia inhibitory factor on preimplantation development and STAT3 signaling of mouse embryos in vitro. Biology of Reproduction 69 $1531-1538$

Fruebis J, Tsao TS, Javorschi S, Ebbets-Reed D, Erickson MR, Yen FT, Bihain BE \& Lodish HF 2001 Proteolytic cleavage product of 30$\mathrm{kDa}$ adipocyte complement-related protein increases fatty acid oxidation in muscle and causes weight loss in mice. PNAS 98 2005-2010.

Garaulet M, Viguerie N, Porubsky S, Klimcakova E, Clement K, Langin D \& Stich V 2004 Adiponectin gene expression and plasma values in obese women during very-low-calorie diet. Relationship with cardiovascular risk factors and insulin resistance. Journal of Clinical Endocrinology and Metabolism $\mathbf{8 9}$ $756-760$.

Garcia MR, Amstalden M, Williams SW, Stanko RL, Morrison CD, Keisler DH, Nizielski SE \& Williams GL 2002 Serum leptin and its adipose gene expression during pubertal development, the estrous cycle, and different seasons in cattle. Journal of Animal Science $\mathbf{8 0}$ $2158-2167$.

Gerstmayer B, Kusters D, Gebel S, Muller T, Van Miert E, Hofmann K \& Bosio A 2003 Identification of RELMgamma, a novel resistinlike molecule with a distinct expression pattern. Genomics $\mathbf{8 1}$ 588-595.

Gong JG 2002 Influence of metabolic hormones and nutrition on ovarian follicle development in cattle: practical implications. Domestic Animal Endocrinology 23 229-241.

Gonzalez RR, Caballero-Campo P, Jasper M, Mercader A, Devoto L, Pellicer A \& Simon C 2000 Leptin and leptin receptor are expressed in the human endometrium and endometrial leptin secretion is regulated by the human blastocyst. Journal of Clinical Endocrinology and Metabolism 85 4883-4888.

Greenfield JR \& Campbell LV 2004 Insulin resistance and obesity. Clinical Dermatology 22 289-295.

Gregoraszczuk EL, Wojtowicz AK, Ptak A \& Nowak K 2003 In vitro effect of leptin on steroids' secretion by FSH- and LH-treated porcine small, medium and large preovulatory follicles. Reproductive Biology 3 227-239.

Gregoraszczuk EL, Ptak A, Wojtowicz AK, Gorska T \& Nowak KW 2004 Estrus cycle-dependent action of leptin on basal and GH or IGF-I stimulated steroid secretion by whole porcine follicles. Endocrine Regulation 38 15-21.

Gui Y, Silha JV \& Murphy LJ 2004 Sexual dimorphism and regulation of resistin, adiponectin, and leptin expression in the mouse. Obesity Research 12 1481-1491. 
Guo X, Chen S \& Xing F 2001 [Effects of leptin on estradiol and progesterone production by human luteinized granulosa cells in vitro]. Zhonghua Fu Chan Ke Za Zhi 36 95-97.

Hakansson ML, Hulting AL \& Meister B 1996 Expression of leptin receptor mRNA in the hypothalamic arcuate nucleus-relationship with NPY neurones. Neuroreport 7 3087-3092.

Halaas JL, Boozer C, Blair-West J, Fidahusein N, Denton DA \& Friedman JM 1997 Physiological response to long-term peripheral and central leptin infusion in lean and obese mice. PNAS 94 8878-8883.

Hamilton-Fairley D, Kiddy D, Watson H, Paterson C \& Franks S 1992 Association of moderate obesity with a poor pregnancy outcome in women with polycystic ovary syndrome treated with low dose gonadotrophin. British Journal of Obstetrics and Gynaecology 99 128-131.

Hardie L, Trayhurn P, Abramovich D \& Fowler P 1997 Circulating leptin in women: a longitudinal study in the menstrual cycle and during pregnancy. Clinical Endocrinology (Oxf) 47 101-106.

Hartz AJ, Barboriak PN, Wong A, Katayama KP \& Rimm AA 1979 The association of obesity with infertility and related menstural abnormalities in women. International Journal of Obesity 3 57-73.

Heilbronn LK, Rood J, Janderova L, Albu JB, Kelley DE, Ravussin E \& Smith SR 2004 Relationship between serum resistin concentrations and insulin resistance in nonobese, obese, and obese diabetic subjects. Journal of Clinical Endocrinology and Metabolism 89 1844-1848.

Henry BA, Goding JW, Alexander WS, Tilbrook AJ, Canny BJ, Dunshea F, Rao A, Mansell A \& Clarke IJ 1999 Central administration of leptin to ovariectomized ewes inhibits food intake without affecting the secretion of hormones from the pituitary gland: evidence for a dissociation of effects on appetite and neuroendocrine function. Endocrinology 140 1175-1182.

Henry BA, Goding JW, Tilbrook AJ, Dunshea FR \& Clarke IJ 2001 Intracerebroventricular infusion of leptin elevates the secretion of luteinising hormone without affecting food intake in long-term food-restricted sheep, but increases growth hormone irrespective of bodyweight. Journal of Endocrinology 168 67-77.

Heymsfield SB, Greenberg AS, Fujioka K, Dixon RM, Kushner R, Hunt T, Lubina JA, Patane J, Self B, Hunt P \& McCamish M 1999 Recombinant leptin for weight loss in obese and lean adults: a randomized, controlled, dose-escalation trial. JAMA 282 1568-1575.

Holcomb IN, Kabakoff RC, Chan B, Baker TW, Gurney A, Henzel W, Nelson C, Lowman HB, Wright BD, Skelton NJ, Frantz GD, Tumas DB, Peale FV Jr, Shelton DL \& Hebert CC 2000 FIZZ1, a novel cysteine-rich secreted protein associated with pulmonary inflammation, defines a new gene family. EMBO Journal 19 4046-4055.

Hu E, Liang P \& Spiegelman BM 1996 AdipoQ is a novel adiposespecific gene dysregulated in obesity. Journal of Biological Chemistry 271 10697-10703.

Huang KC, Lue BH, Yen RF, Shen CG, Ho SR, Tai TY \& Yang WS 2004 Plasma adiponectin levels and metabolic factors in nondiabetic adolescents. Obesity Research 12 119-124.

Huang SW, Seow KM, Ho LT, Chein Y, Chung DY, Chang CL, Lai YH, Hwang JL \& Juan CC 2005 Resistin mRNA levels are down regulated by estrogen in vivo and in vitro. FEBS Letters 579 449-454.

Hug C, Wang J, Ahmad NS, Bogan JS, Tsao TS \& Lodish HF 2004 T-cadherin is a receptor for hexameric and high-molecular-weight forms of Acrp30/adiponectin. PNAS 101 10308-10313.

Hukshorn CJ, Saris WH, Westerterp-Plantenga MS, Farid AR, Smith FJ \& Campfield LA 2000 Weekly subcutaneous pegylated recombinant native human leptin (PEG-OB) administration in obese men. Journal of Clinical Endocrinology and Metabolism 85 4003-4009.

Hunter MG, Robinson RS, Mann GE \& Webb R 2004 Endocrine and paracrine control of follicular development and ovulation rate in farm species. Animal Reproductive Science 82-83 461-477.

Jacobi SK, Ajuwon KM, Weber TE, Kuske JL, Dyer CJ \& Spurlock ME 2004 Cloning and expression of porcine adiponectin, and its relationship to adiposity, lipogenesis and the acute phase response. Journal of Endocrinology 182 133-144.

Juan CC, Au LC, Fang VS, Kang SF, Ko YH, Kuo SF, Hsu YP, Kwok CF \& Ho LT 2001 Suppressed gene expression of adipocyte resistin in an insulin-resistant rat model probably by elevated free fatty acids. Biochemical and Biophysical Research Communications 289 1328-1333.

Kadowaki T, Hara K, Yamauchi T, Terauchi Y, Tobe $\mathrm{K}$ \& Nagai $\mathbf{R}$ 2003 Molecular mechanism of insulin resistance and obesity. Exp Biol Med (Maywood) 228 1111-1117.

Kamohara S, Burcelin R, Halaas JL, Friedman JM \& Charron MJ 1997 Acute stimulation of glucose metabolism in mice by leptin treatment. Nature 389 374-377.

Karlsson C, Lindell K, Svensson E, Bergh C, Lind P, Billig H, Carlsson LM \& Carlsson B 1997 Expression of functional leptin receptors in the human ovary. Journal of Clinical Endocrinology and Metabolism 82 4144-4148.

Kawamura K, Sato N, Fukuda J, Kodama H, Kumagai J, Tanikawa H, Nakamura A \& Tanaka T 2002 Leptin promotes the development of mouse preimplantation embryos in vitro Endocrinology 143 1922-1931.

Kharroubi I, Rasschaert J, Eizirik DL \& Cnop M 2003 Expression of adiponectin receptors in pancreatic beta cells. Biochemical and Biophysical Research Communications 312 1118-1122.

Kim KH, Lee K, Moon YS \& Sul HS 2001 A cysteine-rich adipose tissue-specific secretory factor inhibits adipocyte differentiation. Journal of Biological Chemistry 276 11252-11256.

Kissebah AH, Sonnenberg GE, Myklebust J, Goldstein M, Broman K, James RG, Marks JA, Krakower GR, Jacob HJ, Weber J, Martin L, Blangero J \& Comuzzie AG 2000 Quantitative trait loci on chromosomes 3 and 17 influence phenotypes of the metabolic syndrome. PNAS 97 14478-14483.

Kochan Z \& Karbowska J 2004 Dehydroepiandrosterone up-regulates resistin gene expression in white adipose tissue. Molecular and Cellular Endocrinology 218 57-64.

Komatsu T, Itoh F, Mikawa S \& Hodate K 2003 Gene expression of resistin in adipose tissue and mammary gland of lactating and non-lactating cows. Journal of Endocrinology 178 R1-R5.

Kristensen K, Pedersen SB \& Richelsen B 1999 Regulation of leptin by steroid hormones in rat adipose tissue. Biochemical and Biophysical Research Communications 259 624-630.

Kubota N, Terauchi Y, Yamauchi T, Kubota T, Moroi M, Matsui J, Eto K, Yamashita T, Kamon J, Satoh H, Yano W, Froguel P, Nagai R, Kimura S, Kadowaki T \& Noda T 2002 Disruption of adiponectin causes insulin resistance and neointimal formation. Journal of Biological Chemistry $27725863-25866$.

Lake JK, Power C \& Cole TJ 1997 Women's reproductive health: the role of body mass index in early and adult life. International Journal of Obesity and Related Metabolic Disorders 21 432-438.

Lanfranco F, Zitzmann M, Simoni M \& Nieschlag E 2004 Serum adiponectin levels in hypogonadal males: influence of testosterone replacement therapy. Clinical Endocrinology (Oxf) 60 500-507.

Le Lay S, Boucher J, Rey A, Castan-Laurell I, Krief S, Ferre P, Valet P \& Dugail I 2001 Decreased resistin expression in mice with different sensitivities to a high-fat diet. Biochemical and Biophysical Research Communications 289 564-567.

Lee JH, Chan JL, Yiannakouris N, Kontogianni M, Estrada E, Seip R, Orlova C \& Mantzoros CS 2003 Circulating resistin levels are not associated with obesity or insulin resistance in humans and are not regulated by fasting or leptin administration: cross-sectional and interventional studies in normal, insulin-resistant, and diabetic subjects. Journal of Clinical Endocrinology and Metabolism 88 $4848-4856$.

Lee JH, Bullen JW Jr, Stoyneva VL \& Mantzoros CS 2005 Circulating resistin in lean, obese, and insulin-resistant mouse models: lack of association with insulinemia and glycemia. American Journal of Physiology: Endocrinology and Metabolism 288 E625-E632. 
Lin J, Choi YH, Hartzell DL, Li C, Della-Fera MA \& Baile CA 2003 CNS melanocortin and leptin effects on stearoyl-CoA desaturase-1 and resistin expression. Biochemical and Biophysical Research Communications 311 324-328.

Ling C, Kindblom J, Wennbo H \& Billig H 2001 Increased resistin expression in the adipose tissue of male prolactin transgenic mice and in male mice with elevated androgen levels. FEBS Letters $\mathbf{5 0 7}$ $147-150$.

Liu YM, Lacorte JM, Viguerie N, Poitou C, Pelloux V, Guy-Grand B, Coussieu C, Langin D, Basdevant A \& Clement K 2003 Adiponectin gene expression in subcutaneous adipose tissue of obese women in response to short-term very low calorie diet and refeeding. Journal of Clinical Endocrinology and Metabolism $\mathbf{8 8}$ 5881-5886.

Lord E, Ledoux S, Murphy BD, Beaudry D \& Palin MF 2005 Expression of adiponectin and its receptors in swine. Journal of Animal Science 83 565-578.

Ma K, Cabrero A, Saha PK, Kojima H, Li L, Chang BH, Paul A \& Chan L 2002 Increased beta -oxidation but no insulin resistance or glucose intolerance in mice lacking adiponectin. Journal of Biological Chemistry 277 34658-34661.

Maebuchi M, Machidori M, Urade R, Ogawa T \& Moriyama T 2003 Low resistin levels in adipose tissues and serum in high-fat fed mice and genetically obese mice: development of an ELISA system for quantification of resistin. Archives of Biochemistry and Biophysics 416 164-170.

Maeda K, Okubo K, Shimomura I, Funahashi T, Matsuzawa Y \& Matsubara K 1996 cDNA cloning and expression of a novel adipose specific collagen-like factor, apM1 (AdiPose Most abundant Gene transcript 1). Biochemical and Biophysical Research Communications $221286-289$.

Maeda N, Shimomura I, Kishida K, Nishizawa H, Matsuda M, Nagaretani $\mathbf{H}$, Furuyama N, Kondo $\mathbf{H}$, Takahashi $\mathbf{M}$, Arita $\mathrm{Y}$, Komuro $\mathbf{R}$, Ouchi N, Kihara S, Tochino Y, Okutomi K, Horie M, Takeda S, Aoyama T, Funahashi T \& Matsuzawa Y 2002 Diet-induced insulin resistance in mice lacking adiponectin/ACRP30. Nature Medicine $8731-737$.

Maffei M, Halaas J, Ravussin E, Pratley RE, Lee GH, Zhang Y, Fei H, Kim S, Lallone R, Ranganathan S, Kern PA \& Friedman JM 1995 Leptin levels in human and rodent: measurement of plasma leptin and ob RNA in obese and weight-reduced subjects. Nature Medicine 1 1155-1161.

Makimura H, Mizuno TM, Bergen H \& Mobbs CV 2002 Adiponectin is stimulated by adrenalectomy in ob/ob mice \& is highly correlated with resistin mRNA. American Journal of Physiology: Endocrinology and Metabolism 283 E1266-E1271.

Maroni P, Bendinelli P \& Piccoletti R 2003 Early intracellular events induced by in vivo leptin treatment in mouse skeletal muscle. Molecular and Cellular Endocrinology 201 109-121.

Martin RL, Perez E, He YJ, Dawson R Jr \& Millard WJ 2000 Leptin resistance is associated with hypothalamic leptin receptor mRNA and protein downregulation. Metabolism 49 1479-1484.

Masaki T, Chiba S, Yasuda T, Tsubone T, Kakuma T, Shimomura I, Funahashi T, Matsuzawa Y \& Yoshimatsu H 2003 Peripheral, but not central, administration of adiponectin reduces visceral adiposity and upregulates the expression of uncoupling protein in agouti yellow (Ay/a) obese mice. Diabetes 52 2266-2273.

Masuzaki H, Ogawa Y, Sagawa N, Hosoda K, Matsumoto T, Mise H, Nishimura H, Yoshimasa Y, Tanaka I, Mori T \& Nakao K 1997 Nonadipose tissue production of leptin: leptin as a novel placenta-derived hormone in humans. Nature Medicine $\mathbf{3}$ 1029-1033.

Masuzaki H, Paterson J, Shinyama H, Morton NM, Mullins JJ, Seckl JR \& Flier JS 2001 A transgenic model of visceral obesity and the metabolic syndrome. Science 294 2166-2170.

Matkovic V, Ilich JZ, Skugor M, Badenhop NE, Goel P, Clairmont A, Klisovic D, Nahhas RW \& Landoll JD 1997 Leptin is inversely related to age at menarche in human females. Journal of Clinical Endocrinology and Metabolism 82 3239-3245.
McNeel RL, Ding ST, Smith EO \& Mersmann HJ 2000 Effect of feed restriction on adipose tissue transcript concentrations in genetically lean and obese pigs. Journal of Animal Science 78 934-942.

McTernan CL, McTernan PG, Harte AL, Levick PL, Barnett AH \& Kumar S 2002 Resistin, central obesity, and type 2 diabetes. Lancet 359 46-47.

Mercer JG, Hoggard N, Williams LM, Lawrence CB, Hannah LT, Morgan PJ \& Trayhurn P 1996 Coexpression of leptin receptor and preproneuropeptide $\mathrm{Y}$ mRNA in arcuate nucleus of mouse hypothalamus. Journal of Neuroendocrinology 8 733-735.

Milan G, Granzotto M, Scarda A, Calcagno A, Pagano C, Federspil G \& Vettor R 2002 Resistin and adiponectin expression in visceral fat of obese rats: effect of weight loss. Obesity Research $\mathbf{1 0}$ 1095-1103.

Minokoshi Y, Haque MS \& Shimazu T 1999 Microinjection of leptin into the ventromedial hypothalamus increases glucose uptake in peripheral tissues in rats. Diabetes 48 287-291.

Minokoshi Y, Kim YB, Peroni OD, Fryer LG, Muller C, Carling D \& Kahn BB 2002 Leptin stimulates fatty-acid oxidation by activating AMP-activated protein kinase. Nature 415 339-343.

Mistry AM, Swick AG \& Romsos DR 1997 Leptin rapidly lowers food intake and elevates metabolic rates in lean and ob/ob mice. Journal of Nutrition 127 2065-2072.

Monzillo LU, Hamdy O, Horton ES, Ledbury S, Mullooly C, Jarema C, Porter S, Ovalle K, Moussa A \& Mantzoros CS 2003 Effect of lifestyle modification on adipokine levels in obese subjects with insulin resistance. Obesity Research 11 1048-1054.

Moon B, Kwan JJ, Duddy N, Sweeney G \& Begum N 2003 Resistin inhibits glucose uptake in L6 cells independently of changes in insulin signaling and GLUT4 translocation. American Journal of Physiology: Endocrinology and Metabolism 285 E106-E115.

Morash BA, Willkinson D, Ur E \& Wilkinson M 2002 Resistin expression and regulation in mouse pituitary. FEBS Letters $\mathbf{5 2 6}$ $26-30$.

Morash BA, Ur E, Wiesner G, Roy J \& Wilkinson M 2004 Pituitary resistin gene expression: effects of age, gender and obesity. Neuroendocrinology 79 149-156.

Morrison CD, Daniel JA, Holmberg BJ, Djiane J, Raver N, Gertler A \& Keisler DH 2001 Central infusion of leptin into well-fed and undernourished ewe lambs: effects on feed intake and serum concentrations of growth hormone and luteinizing hormone. Journal of Endocrinology 168 317-324.

Mounzih K, Lu R \& Chehab FF 1997 Leptin treatment rescues the sterility of genetically obese ob/ob males. Endocrinology 138 1190-1193.

Munir I, Yen HW, Baruth T, Tarkowski R, Azziz R, Magoffin DA \& Jakimiuk AJ 2005 Resistin Stimulation of 17\{alpha\}-Hydroxylase Activity in Ovarian Theca Cells In Vitro: Relevance to Polycystic Ovary Syndrome. Journal of Clinical Endocrinology and Metabolism 90 4852-4857.

Murakami T, lida M \& Shima K 1995 Dexamethasone regulates obese expression in isolated rat adipocytes. Biochemical and Biophysical Research Communications 214 1260-1267.

Muse ED, Obici S, Bhanot S, Monia BP, McKay RA, Rajala MW, Scherer PE \& Rossetti L 2004 Role of resistin in diet-induced hepatic insulin resistance. Journal of Clinical Investigation 114 232-239.

Nagaev I \& Smith U 2001 Insulin resistance and type 2 diabetes are not related to resistin expression in human fat cells or skeletal muscle. Biochemical and Biophysical Research Communications $285561-564$.

Nagatani S, Guthikonda P, Thompson RC, Tsukamura H, Maeda KI \& Foster DL 1998 Evidence for GnRH regulation by leptin: leptin administration prevents reduced pulsatile $\mathrm{LH}$ secretion during fasting. Neuroendocrinology 67 370-376.

Nakano Y, Tobe T, Choi-Miura NH, Mazda T \& Tomita M 1996 Isolation and characterization of GBP28, a novel gelatin-binding protein purified from human plasma. Journal of Biochemistry (Tokyo) $120803-812$. 
Nishizawa H, Shimomura I, Kishida K, Maeda N, Kuriyama H, Nagaretani $\mathbf{H}$, Matsuda $\mathbf{M}$, Kondo $\mathbf{H}$, Furuyama $\mathbf{N}$, Kihara $\mathbf{S}$, Nakamura T, Tochino Y, Funahashi T \& Matsuzawa Y 2002 Androgens decrease plasma adiponectin, an insulin-sensitizing adipocyte-derived protein. Diabetes $512734-2741$.

Nogueiras R, Gualillo O, Caminos JE, Casanueva FF \& Dieguez C 2003a Regulation of resistin by gonadal, thyroid hormone, and nutritional status. Obesity Research 11 408-414.

Nogueiras R, Gallego R, Gualillo O, Caminos JE, Garcia-Caballero T, Casanueva FF \& Dieguez C 2003b Resistin is expressed in different rat tissues and is regulated in a tissue- and gender-specific manner. FEBS Letters $54821-27$

Nogueiras R, Barreiro ML, Caminos JE, Gaytan F, Suominen JS, Navarro VM, Casanueva FF, Aguilar E, Toppari J, Dieguez C \& Tena-Sempere M 2004 Novel expression of resistin in rat testis: functional role and regulation by nutritional status and hormonal factors. Journal of Cell Science 117 3247-3257.

Norman RJ \& Clark AM 1998 Obesity and reproductive disorders: a review. Reproduction, Fertility and Development 10 55-63.

Ogura K, Irahara M, Kiyokawa M, Tezuka M, Matsuzaki T, Yasui T, Kamada M \& Aono T 2001 Effects of leptin on secretion of LH and FSH from primary cultured female rat pituitary cells. European Journal of Endocrinology 144 653-658.

Orio F Jr, Palomba S, Cascella T, Milan G, Mioni R, Pagano C, Zullo F, Colao A, Lombardi G \& Vettor R 2003 Adiponectin levels in women with polycystic ovary syndrome. Journal of Clinical Endocrinology and Metabolism 88 2619-2623.

Ort T, Arjona AA, Macdougall JR, Nelson PJ, Rothenberg ME, Wu F, Eisen A \& Halvorsen YD 2005 Recombinant Human FIZZ3/Resistin Stimulates Lipolysis in Cultured Human Adipocytes, Mouse Adipose Explants and in Normal Mice. Endocrinology 146 2200-2209.

Otieno CJ, Bastiaansen J, Ramos AM \& Rothschild MF 2005 Mapping and association studies of diabetes related genes in the pig. Animal Genetics 36 36-42.

Pagano C, Marin O, Calcagno A, Schiappelli P, Pilon C, Milan G, Bertelli M, Fanin E, Andrighetto G, Federspil G \& Vettor R 2005 Increased Serum Resistin in Adults with Prader-Willi Syndrome Is Related to Obesity and Not to Insulin Resistance. Journal of Clinical Endocrinology and Metabolism 90 4335-4340.

Page ST, Herbst KL, Amory JK, Coviello AD, Anawalt BD, Matsumoto AM \& Bremner WJ 2005 Testosterone administration suppresses adiponectin levels in men. Journal of Andrology 26 85-92.

Patel L, Buckels AC, Kinghorn IJ, Murdock PR, Holbrook JD, Plumpton C, Macphee CH \& Smith SA 2003 Resistin is expressed in human macrophages and directly regulated by PPAR gamma activators. Biochemical and Biophysical Research Communications $300472-476$.

Pelleymounter MA, Cullen MJ, Baker MB, Hecht R, Winters D, Boone T \& Collins F 1995 Effects of the obese gene product on body weight regulation in ob/ob mice. Science 269 540-543.

Pettigrew R \& Hamilton-Fairley D 1997 Obesity and female reproductive function. British Medical Bulletin 53 341-358.

Pravenec M, Kazdova L, Landa V, Zidek V, Mlejnek P, Jansa P, Wang J, Qi N \& Kurtz TW 2003 Transgenic and recombinant resistin impair skeletal muscle glucose metabolism in the spontaneously hypertensive rat. Journal of Biological Chemistry 278 45209-45215.

Qian H, Barb CR, Compton MM, Hausman GJ, Azain MJ, Kraeling RR \& Baile CA 1999 Leptin mRNA expression and serum leptin concentrations as influenced by age, weight, and estradiol in pigs. Domestic Animal Endocrinology 16 135-143.

Raitakari M, Ilvonen T, Ahotupa M, Lehtimaki T, Harmoinen A, Suominen P, Elo J, Hartiala J \& Raitakari OT 2004 Weight reduction with very-low-caloric diet and endothelial function in overweight adults: role of plasma glucose. Arteriosclerosis, Thrombosis and Vascular Biology 24 124-128.

Rajala MW, Obici S, Scherer PE \& Rossetti L 2003 Adipose-derived resistin and gut-derived resistin-like molecule-beta selectively impair insulin action on glucose production. Journal of Clinical Investigation $111225-230$.
Rajala MW, Qi Y, Patel HR, Takahashi N, Banerjee R, Pajvani UB, Sinha MK, Gingerich RL, Scherer PE \& Ahima RS 2004 Regulation of resistin expression and circulating levels in obesity, diabetes, and fasting. Diabetes 53 1671-1679.

Ramsay TG, Bush JA, McMurtry JP, Thivierge MC \& Davis TA 2004 Peripheral leptin administration alters hormone and metabolite levels in the young pig. Comparitive Biochemistry and Physiology Part A: Molecular \& Integrative Physiology $13817-25$.

Rangwala SM, Rich AS, Rhoades B, Shapiro JS, Obici S, Rossetti L \& Lazar MA 2004 Abnormal glucose homeostasis due to chronic hyperresistinemia. Diabetes 53 1937-1941.

Remsberg KE, Talbott EO, Zborowski JV, Evans RW \& McHugh-Pemu K 2002 Evidence for competing effects of body mass, hyperinsulinemia, insulin resistance, and androgens on leptin levels among lean, overweight, and obese women with polycystic ovary syndrome. Fertility and Sterility 78 479-486.

Ryan NK, Woodhouse CM, Van der Hoek KH, Gilchrist RB, Armstrong DT \& Norman RJ 2002 Expression of leptin and its receptor in the murine ovary: possible role in the regulation of oocyte maturation. Biology of Reproduction 66 1548-1554.

Sagawa N, Yura S, Itoh H, Mise H, Kakui K, Korita D, Takemura M, Nuamah MA, Ogawa Y, Masuzaki H, Nakao K \& Fujii S 2002 Role of leptin in pregnancy-a review. Placenta 23 Suppl A S80-S86.

Sahu A 2004 Minireview: A hypothalamic role in energy balance with special emphasis on leptin. Endocrinology 145 2613-2620.

Saito K, Tobe T, Minoshima S, Asakawa S, Sumiya J, Yoda M, Nakano Y, Shimizu N \& Tomita M 1999 Organization of the gene for gelatin-binding protein (GBP28). Gene 229 67-73.

Savage DB, Sewter CP, Klenk ES, Segal DG, Vidal-Puig A, Considine RV \& O'Rahilly S 2001 Resistin/Fizz3 expression in relation to obesity and peroxisome proliferator-activated receptor-gamma action in humans. Diabetes $502199-2202$.

Scherer PE, Williams S, Fogliano M, Baldini G \& Lodish HF 1995 A novel serum protein similar to $\mathrm{C} 1 \mathrm{q}$, produced exclusively in adipocytes. Journal of Biological Chemistry $27026746-26749$.

Senaris R, Garcia-Caballero T, Casabiell X, Gallego R, Castro R, Considine RV, Dieguez C \& Casanueva FF 1997 Synthesis of leptin in human placenta. Endocrinology 1384501 - 4504.

Seow KM, Juan CC, Wu LY, Hsu YP, Yang WM, Tsai YL, Hwang JL \& Ho LT 2004 Serum and adipocyte resistin in polycystic ovary syndrome with insulin resistance. Human Reproduction 19 48-53.

Seow KM, Juan CC, Hsu YP, Ho LT, Wang YY \& Hwang JL 2005 Serum and follicular resistin levels in women with polycystic ovarian syndrome during IVF-stimulated cycles. Human Reproduction $20117-121$.

Sepilian V \& Nagamani M 2005 Adiponectin levels in women with polycystic ovary syndrome and severe insulin resistance. Journal of the Society for Gynecological Investigation 12 129-134.

Seufert J 2004 Leptin effects on pancreatic beta-cell gene expression and function. Diabetes 53 Suppl 1 S152-S158.

Sieminska L, Marek B, Kos-Kudla B, Niedziolka D, Kajdaniuk D, Nowak M \& Glogowska-Szelag J 2004 Serum adiponectin in women with polycystic ovarian syndrome and its relation to clinical, metabolic and endocrine parameters. Journal of Endocrinological Investigation 27 528-534.

Spicer LJ \& Francisco CC 1997 The adipose obese gene product, leptin: evidence of a direct inhibitory role in ovarian function. Endocrinology 138 3374-3379.

Spicer LJ \& Francisco CC 1998 Adipose obese gene product, leptin, inhibits bovine ovarian thecal cell steroidogenesis. Biology of Reproduction 58 207-212.

Spicer LJ, Chamberlain CS \& Francisco CC 2000 Ovarian action of leptin: effects on insulin-like growth factor-I-stimulated function of granulosa and thecal cells. Endocrine 12 53-59.

Steinberg GR, Rush JW \& Dyck DJ 2003 AMPK expression and phosphorylation are increased in rodent muscle after chronic leptin treatment. American Journal of Physiology: Endocrinology and Metabolism 284 E648-E654. 
Steppan CM, Bailey ST, Bhat S, Brown EJ, Banerjee RR, Wright CM, Patel HR, Ahima RS \& Lazar MA 2001 The hormone resistin links obesity to diabetes. Nature 409 307-312.

Steppan CM \& Lazar MA 2002 Resistin and obesity-associated insulin resistance. Trends in Endocrinology and Metabolism 13 18-23.

Swain JE, Dunn RL, McConnell D, Gonzalez-Martinez J \& Smith GD 2004 Direct effects of leptin on mouse reproductive function: regulation of follicular, oocyte, and embryo development. Biology of Reproduction 71 1446-1452.

Tomas E, Tsao TS, Saha AK, Murrey HE, Zhang Cc C, Itani SI, Lodish HF \& Ruderman NB 2002 Enhanced muscle fat oxidation and glucose transport by ACRP30 globular domain: acetyl-CoA carboxylase inhibition and AMP-activated protein kinase activation. PNAS 99 16309-16313.

Tortoriello DV, McMinn J \& Chua SC 2004 Dietary-induced obesity and hypothalamic infertility in female DBA/2J mice. Endocrinology $1451238-1247$

Tsai EM, Yang CH, Chen SC, Liu YH, Chen HS, Hsu SC \& Lee JN 2002 Leptin affects pregnancy outcome of in vitro fertilization and steroidogenesis of human granulosa cells. Journal of Assisted Reproduction and Genetics 19 169-176.

Van Heek $M$, Compton DS, France CF, Tedesco RP, Fawzi AB, Graziano MP, Sybertz EJ, Strader CD \& Davis HR Jr 1997 Dietinduced obese mice develop peripheral, but not central, resistance to leptin. Journal of Clinical Investigation 99 385-390.

Vicennati V, Gambineri A, Calzoni F, Casimirri F, Macor C, Vettor R \& Pasquali R 1998 Serum leptin in obese women with polycystic ovary syndrome is correlated with body weight and fat distribution but not with androgen and insulin levels. Metabolism 47 988-992.

Viguerie N, Vidal H, Arner P, Holst C, Verdich C, Avizou S, Astrup A, Saris W, Macdonald I, Klimcakova E, Clement K, Martinez A, Hoffstedt J, Sorensen T \& Langin D 2005 Adipose tissue gene expression in obese subjects during low-fat and high-fat hypocaloric diets. Diabetologia 48 123-131.

Vionnet N, Hani El H, Dupont S, Gallina S, Francke S, Dotte S, De Matos F, Durand E, Lepretre F, Lecoeur C, Gallina P, Zekiri L, Dina C \& Froguel P 2000 Genomewide search for type 2 diabetessusceptibility genes in French whites: evidence for a novel susceptibility locus for early-onset diabetes on chromosome 3q27-qter and independent replication of a type 2-diabetes locus on chromosome 1q21-q24. American Journal of Human Genetics 67 $1470-1480$.

Wadden TA, Considine RV, Foster GD, Anderson DA, Sarwer DB \& Caro JS 1998 Short- and long-term changes in serum leptin dieting obese women: effects of caloric restriction and weight loss. Journal of Clinical Endocrinology and Metabolism 83 214-218.

Wallenius V, Wallenius K, Ahren B, Rudling M, Carlsten H, Dickson SL, Ohlsson C \& Jansson JO 2002 Interleukin-6-deficient mice develop mature-onset obesity. Nature Medicine 8 75-79.

Wang JX, Davies MJ \& Norman RJ 2002 Obesity increases the risk of spontaneous abortion during infertility treatment. Obesity Research $10551-554$.

Way JM, Gorgun CZ, Tong Q, Uysal KT, Brown KK, Harrington WW, Oliver WR Jr, Willson TM, Kliewer SA \& Hotamisligil GS 2001 Adipose tissue resistin expression is severely suppressed in obesity and stimulated by peroxisome proliferator-activated receptor gamma agonists. Journal of Biological Chemistry $27625651-25653$.

Weber TE \& Spurlock ME 2004 Leptin alters antibody isotype in the pig in vivo, but does not regulate cytokine expression or stimulate STAT3 signaling in peripheral blood monocytes in vitro. Journal of Animal Science 82 1630-1640.

Whisnant CS \& Harrell RJ 2002 Effect of short-term feed restriction and refeeding on serum concentrations of leptin, luteinizing hormone and insulin in ovariectomized gilts. Domestic Animal Endocrinology $2273-80$.

Wilkinson M, Wilkinson D, Wiesner G, Morash B \& Ur E 2005 Hypothalamic Resistin Immunoreactivity Is Reduced b y Obesity in the Mouse: Co-Localization with alpha-Melanostimulating Hormone. Neuroendocrinology 81 19-30.
Winzell MS, Nogueiras R, Dieguez C \& Ahren B 2004 Dual action of adiponectin on insulin secretion in insulin-resistant mice. Biochemical and Biophysical Research Communications 321 154-160.

Wolfe BE, Jimerson DC, Orlova C \& Mantzoros CS 2004 Effect of dieting on plasma leptin, soluble leptin receptor, adiponectin and resistin levels in healthy volunteers. Clinical Endocrinology (Oxf) $61332-338$.

Woller M, Tessmer S, Neff D, Nguema AA, Roo BV \& WaechterBrulla D 2001 Leptin stimulates gonadotropin releasing hormone release from cultured intact hemihypothalami and enzymatically dispersed neurons. Experimental Biology and Medicine (Maywood) $226591-596$.

Wu X, Motoshima H, Mahadev K, Stalker TJ, Scalia R \& Goldstein BJ 2003 Involvement of AMP-activated protein kinase in glucose uptake stimulated by the globular domain of adiponectin in primary rat adipocytes. Diabetes 52 1355-1363.

Xydakis AM, Case CC, Jones PH, Hoogeveen RC, Liu MY, Smith EO, Nelson KW \& Ballantyne CM 2004 Adiponectin, inflammation, and the expression of the metabolic syndrome in obese individuals: the impact of rapid weight loss through caloric restriction. Journal of Clinical Endocrinology and Metabolism 89 2697-2703.

Yamauchi T, Kamon J, Waki H, Terauchi Y, Kubota N, Hara K, Mori Y, Ide T, Murakami K, Tsuboyama-Kasaoka N, Ezaki O, Akanuma Y, Gavrilova O, Vinson C, Reitman ML, Kagechika H, Shudo K, Yoda M, Nakano Y, Tobe K, Nagai R, Kimura S, Tomita M, Froguel P \& Kadowaki T 2001 The fat-derived hormone adiponectin reverses insulin resistance associated with both lipoatrophy and obesity. Nature Medicine 7 941-946.

Yamauchi T, Kamon J, Minokoshi Y, Ito Y, Waki H, Uchida S, Yamashita S, Noda M, Kita S, Ueki K, Eto K, Akanuma $Y$, Froguel P, Foufelle F, Ferre P, Carling D, Kimura S, Nagai R, Kahn BB \& Kadowaki T 2002 Adiponectin stimulates glucose utilization and fatty-acid oxidation by activating AMP-activated protein kinase. Nature Medicine 8 1288-1295.

Yamauchi T, Kamon J, Ito Y, Tsuchida A, Yokomizo T, Kita S, Sugiyama T, Miyagishi M, Hara K, Tsunoda M, Murakami K, Ohteki T, Uchida S, Takekawa S, Waki H, Tsuno NH, Shibata Y, Terauchi Y, Froguel P, Tobe K, Koyasu S, Taira K, Kitamura T, Shimizu T, Nagai R \& Kadowaki T 2003 Cloning of adiponectin receptors that mediate antidiabetic metabolic effects. Nature 423 762-769.

Yannakoulia M, Yiannakouris N, Bluher S, Matalas AL, Klimis-Zacas D \& Mantzoros CS 2003 Body fat mass and macronutrient intake in relation to circulating soluble leptin receptor, free leptin index, adiponectin, and resistin concentrations in healthy humans. Journal of Clinical Endocrinology and Metabolism 88 1730-1736.

Yu WH, Kimura M, Walczewska A, Karanth S \& McCann SM 1997 Role of leptin in hypothalamic-pituitary function. PNAS $\mathbf{9 4}$ $1023-1028$.

Yura S, Sagawa N, Itoh H, Kakui K, Nuamah MA, Korita D, Takemura M \& Fujii S 2003 Resistin is expressed in the human placenta. Journal of Clinical Endocrinology and Metabolism $\mathbf{8 8}$ 1394-1397.

Zaadstra BM, Seidell JC, Van Noord PA, te Velde ER, Habbema JD, Vrieswijk B \& Karbaat J 1993 Fat and female fecundity: prospective study of effect of body fat distribution on conception rates. British Medical Journal 306 484-487.

Zachow RJ \& Magoffin DA 1997 Direct intraovarian effects of leptin: impairment of the synergistic action of insulin-like growth factor-I on follicle-stimulating hormone-dependent estradiol-17 beta production by rat ovarian granulosa cells. Endocrinology 138 847-850.

Received 6 June 2005

First decision 21 July 2005

Revised manuscript received 9 September 2005

Accepted 9 September 2005 